\title{
THE INFLUENCE OF POSITIVISM PHILOSOPHY ON CRIMINAL LAW ENFORCEMENT IN INDONESIA
}

\author{
Bambang Ali Kusumo \\ Faculty of Law, University of Slamet Riyadi \\ Email:
}

\begin{abstract}
Criminal law enforcement in Indonesia may lack of the justice sense and furthermore highlight the rule of law, this is due to the influence of the philosophy of positivism developed in Europe mainland which has liberal-individualist ideology. This ideology wants everything to be rational and certainty, including legal issues must be no certainty. The purpose of this matter is to protect the rights of individuals. While the Indonesian society is a society that does not highlight the rights of individuals, but respects the balance between individual rights and collective rights. Thus, our criminal law enforcement is still sourced from Indonesian Penal Code which is a replica of the Wetboek Van Strafrech (WVS) created by the Dutch colonialists Government will not materialize justice. It is necessary to face these issues with two steps as the following i.e, first one: the law enforcement agencies in using the law needs a more progressive interpretation, therefore a sense of justice can be realized. Second one, it needs to be realized in accordance with the criminal law reform ideology of kinship based on the values of Pancasila as an ideology of the Indonesia. Such measures are expected to materialize justice in the criminal law enforcement of Indonesia.
\end{abstract}

Keywords: Criminal Law, Law Enforcement, Justice.

\section{A. INTRODUCTION}

In the mass media, whether in the form of electronic or non electronic appear much criticism issued by the community against criminal law enforcement in Indonesia. Criticism is not only a criminal law enforcement in the courts but also the level of investigation, prosecution level to the level of execution in prison. This criticism related to the treatment of the less fair law enforcement in handling cases or criminal cases. It seems the preferred / pursued by law enforcement officials which only concern a legal certainty, regardless of the sense of justice. It can be seen from several cases handled by law enforcement officials as a mbok Rasminah case (Decision of Supreme Court Number 653 K / Pid / 2011), mbok Minah (accused as three cacao thief), the case of flip-flops by teenage thieves AAL (Bulletin Komisi Yudisial, January-February 2012: 9), mbok Asyani on the timber thieft cases (Republika, March 19, 2015) and others. Based oh those cases, law enforcement officials, especially the police (investigator) as the cutting edge of law enforcement officers should have to sift, to be 
forwarded or not forwarded to the public prosecutor, because there are few actual losses incurred (see Letter of Chief of Police Number Pol: B / 3022 / XII / 2009 / SDEop, dated December 14, 2009 on the Handling of Cases Through Alternative Dispute Resolution / ADR). But the police still as investigators who follow up or continue to the level of prosecution. Such actions are carried out under the pretext that the elements of the crime meets the requirements to be forwarded. Then at the level of prosecution, after having inspection, it has met the requirements continuously transferred to the court. Furthermore, in the courts, after being questioned by the judge who was given the verdict, that verdict to punish the defendant with a sentence of imprisonment. This description is clear that the law enforcement is rigid, not discretionary and tend to ignore the sense of justice because it prefers the rule of law. Prosecuting is not a mere juridical process in reality. The judicial process is not only the process of applying the articles and the sound of the legislation, but also a process involving behaviors of society and takes place in a given social structure. The study conducted by Marc Galanter in the United States of Amerika can show that a judge's decision is just supposing any endorsement of the agreements reached by the parties. In a sociological perspective, the judiciary is an institution that is multi-functional and a place for record keeping, site of administrative processing, ceremonial changes of status setlement negotiation, mediations and arbitration, and warfare (Marc Galanter in Zudan Arif Fakhrulloh, 2005: 24).

Besides that, there are many cases in which are nominally not set in the criminal laws, but sociologically very harmful to society. It is likely the case of adultery committed by Ariel Peterpen and Luna Maya (Arriemarrioza, 2011: 1). In this case the crime of adultery does not become the target of law enforcement officers, but the target is a criminal offense in violation of Article 29 in conjunction with Article 44 of Law Number 44 of 2008 on Pornography in conjunction with Article 27 paragraph (1) in conjunction with Article 45 of Law Number 11 of 2008 on Information and Electronic Transactions in conjunction with Article 56 of the 2nd Indonesian Penal Code. The public prosecutor charged the defendant actors and the circulation of pornographic videos, Ariel Peterpen imposed a imprisonment for five years and fines of Rp.250,000,000.00. Based on the trial of the Bandung District Court, Judge declared that Ariel Peterpen proven legally and convincingly of committing criminal offenses as well as provides an opportunity for others to spread pornography and the judges gave the decision to the sentence of three years and six months in prison and fines of $\mathrm{Rp} 250,000,000.00$ (two hundred fifty million rupiah). If the fine is not paid, it can be changed to imprisonment of 
three months. In this case the crime of adultery is not examined, because Indonesian Penal Code called adultery is an act performed by two people who are not married (Article 284 paragraph (1) Indonesian Penal Code. Ariel and Luna Maya are two adult people who are not tied to a marital relationship. According to this condition, the Indonesian Penal Code could not reach.

There are some women, namely Euis Sunarti, Rita Hendrawaty Soebagyo, Dinar Dewi Kania, Sitaresmi Sulistyawati Soekanto, Nurul Hidayati Kusumahastuti Ubaya and proposed a judicial review, especially for the Article 284 of Indonesian Penal Code to the Constitutional Court that Article deprives the word "married", so it will make the expansion of meaning could be convicted of zina (Republika, 14 september 2016).

Based on the above case, it describes that law enforcement officers can not be enforced in order to achieve justice in society. On the one hand, there are some cases in order to realize justice law enforcement in which do not need to resolve through the criminal justice system, which is pursued and resolved through mediation and empower the Supreme Court Regulation Number 02 of 2012 on Limitation Adjustment light crime and the amount of fines in the Indonesian Penal Code, but the reason of the nature elements against the law are met, then law enforcement should be completed through the criminal justice system. On the other hand there is a case sociologically which is very detrimental to the public and not resolved through the criminal justice system because there is no criminal rules which are violated.

\section{B. PROBLEM STATEMENT}

According to the above introduction, author want to observe some problems as the following i.e:

1. why law enforcement officials are more concerned with legal certainty of the justice?

2. How the efforts should we attempt to solve it?.

\section{RESEARCH METHOD}

The method used in this study is a qualitative empirical juridical approach. This interdisciplinary method is useful to get a thorough description related to facts of an implementation of a policy and its social impact. The data collection technique was carried out by in-depth interview on sample of informen that were selected purposively or with special criteria determined by researcher based on the focus problem being studied 


\section{RESEARCH RESULT AND DISCUSSION}

The legal system is applied at the moment coming from the history of the development of the legal system in Indonesia. We realize that Indonesia before having independence on August 17, 1945 has been colonized by the Dutch colonialists for three and a half centuries, in which its legal system used in the colony came from the Dutch Law, whereas the origin of Dutch Law was from French Law (Satjipto Rahardjo, 1991: 235).

After Indonesia's independence, the Most of Dutch Law was still applicable to be used. The legal basis of the Dutch Law application is based on the Article II of the Transitional Provisions of the 1945 Constitution, which states that "All state agencies and the existing rules are still effective immediately, as long as the new rules has not held under this Constitution". The purpose of this provision is to avoid a legal vacuum. At that time it can be said that the influence of Dutch law system is still very strong.

It can be understood that the liberal-individualist concept as the philosophy of rationalism in human life. The framework of this rationalization is also a social order or social condition that is likely to affect the Indonesian life. (Satjipto Rahardjo, 2006: 134). Therefore the development of the legal philosophy that respond to the challenges of the needs mentioned above, namely that the law must be in writing form. Because the law is written and made by the authorized organ, then all matters can be foreseen or predicted. Modern philosophy is the philosophy underlying the emergence of positivism, in which was born in the early 19th century (Lili Wyasa Rasyidi and Ida Bagus Putra, 2012: 116). The main principle of the positivism philosophy i.e: first, it just consider what actually appears in experience; second, it must be known and recognized as the real truth. Third, because all truth is gained through knowledge, then the task of philosophy is to regulate the science results of the investigation. The flow of this philosophy evolved in social sciences and jurisprudence. In sociological positivism, regarded as a purely social phenomenon, whereas in legal positivism regarded as a normative phenomenon. (Lili Wyasa Rasyidi and Ida Bagus Putra, 2012: 117).

The existence of legal positivism philosophy is affected by John Austin and Hans Kelsen ideas. John Austin said that: first, the law is a command authorities; secondly, the law is a system of logic that are fixed and closed; Third, the positive law must comply with several elements, namely the elements (command), sanctions (sanction), liabilities (duty), and sovereignty Souvereighnity) (Tanya L. Bernard, 2010: 120). Furthermore, these opinions 
need to be considered the principal teachings of John Austin Analytical Juriprudence as follows (Lili Rasyidi and Ira Thania Rasyidi, 2007: 59-60):

1. The teaching is not related to a matter or assessment, because the votes are outside the legal field;

2. Although the legal positivism recognized their moral laws that affect the community, but it are legally not important to the law.;

3. The essence of the law is a command. All positive law is the command of the sovereign / ruler;

5. Sovereignty is outside the law, which is located at the world of politics or sociology;

6. There is no chance for the law in the society.

Related to the above description. it talks about the law equated to discuss certain and exact sciences. Related to the legal certainty that is characteristic of modern law (positivist) meaning that the law can provide the predictability or unpredictability. Related to this legal certainty Satjipto Rahardjo (Satjipto Rahardjo, 2006: 136)

To maintain legal certainty, the law must be written and usually made in the form of regulations. Regulations or laws are made by competent authorities based on the problems that arise at the time. The natural and social life are not fixed and closed, but constantly changing and moving dynamically, so that when this legislation used for resolving a problem, it will arise injustice in society. (Satjipto Rahardjo, 2009: 27).

Related to this problem, Gustav Radbruch contributed idea, namely cita law. Cita Law will guide humanity in a lawless life. Furthermore, it is supported by the presence of three basic values (grundwerten), namely justice (gerechtigkeit), utility (zweckmaeszigkeit), and the rule of law (rechtssicherkeit). These three basic values are not always in harmonious relationship (harmony) with each other.(Satjipto Raharjo, 2006: 135).

According to the above description, the enforcement of criminal law in Indonesia is very visible affected by the philosophy of positivism. This is due to the basic rules in the completion of a criminal offense are still using the Indonesian Penal Code which is a translation of Wet Boek Van Strafrecht (WVS) based on the concordance principle. Indeed, the Indonesian Penal Code has undergone several changes tailored to the nature of independence, but the spirit of the Indonesian Penal Code is different from the culture of Indonesian society. As a result in the enforcement of criminal law generated a lot of injustice. In addition, we still use the legal education curriculum instituted legal scholar who mastered 
the science of law, the result of law enforcement when it became merely a mouthpiece statute and are pursued only legal certainty regardless of the value of justice. Such conditions whether to run continuously, of course not. Efforts should be made to overcome them.

Criminal law enforcement in Indonesia is influenced by the philosophy of positivism, in which the Civil Law System is still used as the legal system. The main objective system of civil law is not justice but legal certainty. If the legislation does not say explicitly that an act is a crime, then there will be no law violated. Thus, he will be free from punishment. This is in accordance with the principle of legality (Article 1 paragraph 1 of the Indonesian Penal Code), known as Nullum Delictum Nulla poena sine praevia Poenali Lege. Many cases or cases that sociologically harm the public (when viewed from the nature of the unlawful material), but it legally does not violate the law (conducted by Adelinlis free in District Curt Riau), and the case of Ariel Peterpan and Luna Maya who only violate the Information and Electronic Transactions and Pornography Law.

\section{Interpretation of Laws or the Act Progressive.}

Legislation or regulations made by the competent institutions will always miss the event or fact in the community, because the social conditions of society is always moving and changing, while the law remains unchanged. If the law is applied in accordance with the text sound legislation, it would appear injustice. Therefore, there will be no law enforcement according to only the text, words, and sentences but if we are going to enforce the law, it must be projected against a new idea or understanding, which dived to a depth of legal meaning (Satjipto Rahardjo, 2009: 54).

Method of legal interpretation is a method for interpreting the text of the legislation which is not clear, so that the legislation can be applied to certain concrete events. According to Satjipto Rahardjo idea, he said that we should be a progressive interpretation of the law. Where one chapter of the same law can be given to the different meanings (Satjipto Raharjo, 2006: 139). As practiced by Judge Bismar Siregar. Bismar Siregar in cases of "Seducer Rags" in the Medan High Court Registered number: 144 / PID / 1983 / PT.Mdn has interpreted Article 378 of the Indonesian Penal Code that expands the definition of objects including the "chastity of a woman". The interpretation made by Judge Siregar Bismar including progressive interpretation. In practice, it must be admitted, it is often found that a problem that has not been regulated by law but it does not set out clearly and completely. Sudikno Mertokusumo said that there will be no law or statute as 
complete or clear law. Therefore, if the laws are unclear or incomplete should be explained or supplemented by rechtsfinding (Bambang Sutiyoso, 2009: 150).

In Law Number 48 of 2009 on on Judicial Power, especially for Article 10 paragraph (1) states that the court may not refuse to examine and adjudicate a case filed on the grounds that the law does not exist or is less clear, but obliged to examine and hear. This law can be interpreted in written law (legislation) and unwritten law (customary law). This is confirmed in Article 5 (1) of the Law Number 48 of 2009 which states that the Judge shall explore, and understand the values of law and justice in the society. The provisions of that article relates to the Judge in carrying out duties and obligations to examine, hear and decide a case.

There can be occured a problem that is clearly normative legal certainty has not necessarily meet the public's sense of justice. The converse is not necessarily something that is fair in accordance with the statutory provisions. Further to ponder Bismar Siregar opinion stating that judges must be dare to interpret the law so that the law serves as a living law, because the judge did not merely enforce formal rules, but it must also find a justice who live in middle- community. Thomas Aquinas said that the essence of law is justice, because it is an unjust law is not law (Bambang Sutiyoso in Bambang Ali Kusumo, 2010: 9-11)). Then Gustav Radbruch also stated that the purpose of law is the rule of law, justice and expediency. Of the three objectives that justice should be placed first and foremost of the certainty and expediency (Tanya L. Bernard, 2010: 129).

\section{Legal Reform.}

This way to renew the law, either by revising the law or by changing the laws that are not in accordance with the conditions of the community. Indonesian Penal Code made by liberal Western philosophy-individual should be immediately replaced the Indonesian Penal Code made by the local wisdom or values of Indonesia. Indonesian Penal Code which has been the basis of settlement of any criminal act which is in force for decades in fact is not in accordance with the development of social life in the community, but it has not been replaced now. The desire of the replacement of the Indonesian Penal Code already done, starting in 1964, it has been initiated to make the concept of the Indonesian Penal Code. Yet, Until now it published a concept that has undergone some improvements or rectification. The latter concept is the concept of the Indonesian Penal Code in 2012. The replacement is based on the values of Pancasila ideology which became the nation of 
Indonesia. The author will show some provisions to address some of the issues or facts that arise or exist in society, among other requirements or the principles of the criminal prosecution and the protection of the community, the victim and the perpetrator (Bambang Ali Kusumo, 2015: 1696).

a. The principle terms or Punishment

In the Indonesian Penal Code just look at the three main issues, namely the crime of criminal law, tort and criminal, then the formulation of criminal punishment is a manifestation of the offense and a mistake or criminal liability. From this view, it is not visible and variable "destination". This happens because the explicit purpose of punishment is not shown in the general rules of the Indonesian Penal Code (in chapter one). With conditions or models there is justification for their criminal lies only in Crime (objective requirements) and error (a subjective condition). Of things so if two conditions has been proven, it is absolute or absolutely criminal to be there. By looking at such, there is a certainty, but this certainty are rigid or inflexible. Such conditions would be trouble if they found cases which terms (objective and subjective) proved but the suspect is "inexcusable" (Barda Nawawi Arief, 2009: 39). As case mbok Minah, where the judge (court) wanted the mbok Minah was pardoned or forgiven or not convicted, but Judge was difficult to avoid the provisions within the Indonesian Penal Code in which does not allow the judge to do or not to punish her. The judges still punish mbok Minah in accordance with existing rules in the Indonesian Penal Code. There was indiscriminate that time does not mean sentenced / convicted, he remains considered guilty and accountable. There had been indiscrimination of mbok Minah when the decision was made, because Judge punish or criminalize mbok Minah was equal to incarceration (Bulletin Volume VI of the Judicial Commission of January - February 2012: 9). According to the author, this court decision actually has been trying to bring about justice, but the constraints of rules or laws that limit causes championed justice is not maximized.

This case shows that the forgiveness idea (pardon rechterlijk) as if it has no place or at least it is difficult to be accepted among law enforcement agencies. The tendency of the majority of law enforcement or law enforcement (investigators, prosecutors and judges) minded positivists, who pursued only mere legal certainty and regardless of the sense of justice that people want (Bambang Ali Kusumo, 2015: 1697). There is still no law enforcement minded to give priority to justice than the rule of law, such as Karanganyar District Court judge handling the case or cases Lanjar Sriyanto. In 
this case the District Court Karanganyar decided that the defendant Lanjar Sriyanto has been proven legally and convincingly of committing criminal offenses due to negligence causing death of another person and wounded in such a way that it becomes ill for a while, but it can not be blamed and punished for that offense on the basis of circumstances force (Decision of the Supreme Court Number 1926 K / PID / 2010: 5).

The only unfortunated case or this case is appealed by the Prosecutor to the High Court in Semarang and a high court decision to punish Lanjar Sriyanto by imprisonment for one month. The defendant filed an appeal to the Supreme Court. Then the Supreme Court gave its verdict that Lanjar Sriyanto still considered mistakes and should be responsible for his actions, it is concerned the same subject to imprisonment. When you see some above cases, it seems Karanganyar District Court had launched "Progressive Law". Prof. Dr Satjipto Rahardjo argues that the law is for man, So whenever there is a problem of law, the law should be reviewed and corrected to adjust to the law. Law is not an institution that is absolute and final; it is very dependent on how people view and use (Satjipto Rahardjo, 2009: 5).

b. The protection of the public, victims and offenders

It is set in the Concept of the draft of Indonesian Penal Code on sentencing guidelines on Article 55 and Article 56:

\section{Article 55}

(1) In the punishment shall be considered: a. errors maker crime; b. the motive and the purpose of committing a criminal act; c. inner attitude maker crime; d. criminal offenses committed whether planned or unplanned; e. way of committing a crime; $f$. attitudes and actions of after committing a crime; g. biography, the social and economic circumstances maker crime; $h$. criminal influence on the future of the manufacturer of a crime; i. the effect of criminal acts against the victim or the victim $\neg$ ke $\neg$ luarga; $j$. forgiveness from victims and / or their families; and / or k. society's view of crime that $\neg$ dilakukan. (2) The lightness of the act, maker of personal circumstances, or kea $\neg$ daan at the time of the act or that ensues, can be used as a basis for consideration to not convict or apply measures taking into account the aspect of justice and humanity. 
Article 56

A person who commits an offense is not exempt from criminal responsibility, if the person has deliberately caused circumstances that may be the reason the suppression of crime.

Based on these provisions, there are three guidelines, namely: 1. Guidelines for the convict 2. Guidelines to forgive or not to drop the criminal / action 3 . Guidelines to still be able to convict even if there is reason criminal eraser.

Ad 1. Guidelines for the convict

In Article 55 paragraph (1) there is a checklist that can be considered by the judge before the convict. The list in Article 55 paragraph (1), according to the explanation of that chapter is not limiting, meaning that judges are still allowed to add if necessary in accordance with the consideration of the judge.

This provision includes sentencing guidelines were very helpful in considering the measure or judge the severity of the punishment to be imposed. Taking into account the matters specified in the guidelines is expected sentence imposed is proportionate and can be understood both by society and the convict. The details of this provision is not limiting, meaning that the judge may add other considerations other than those listed in paragraph (1) of this. The element of "planning" as found in the Code of Penal old, were not included in the formulation of offenses contained in the articles of the Second Book. Not publishing this element does not mean that the element of planning was abolished, but it is more prudent to be explained in the explanation of paragraph (1) of this. Based on this, then the dropping of criminal judges must always pay attention to the element of planning, fault maker criminal acts, motives, and objective of the criminal act, how to commit criminal acts, and the inner attitude maker criminal offense.

Ad. 2. Guidelines to forgive or not to drop the criminal / action based on the provision of Article 55 paragraph (2) regulating the forgiveness of judges. In this guideline also included guidelines for not criminalize although it has been proven offenses and errors. Guidelines do not criminalize it as the first: the lightness of an act or a criminal act, second: personal circumstances maker / doer, third: the circumstances at the time the 
act was committed or thereafter and consideration in terms of justice and humanity. The elucidation of Article 55 paragraph (2) states:

The provisions of this paragraph is known as the principle of rechterlijke pardon which authorizes judges to grant pardon to a person who is guilty of criminal acts that are mild (not serious). Pardon is included in the judge's decision and remains to be stated that the accused guilty of criminal acts against her.

Ad. 3. Guidelines are still be able to convict even if there is reason criminal eraser. In the draft of the Article 56 Concept of the Criminal Code are also guidelines for judges to remain criminalize the perpetrators although there is no reason to ignore a criminal.

\section{CLOSING}

According to the description, the authors have described that the criminal law enforcement in Indonesia is strongly influenced by the philosophy of positivism arising from the ideology developed in mainland Europe which is liberal-individualist nature. This ideology wants to look that everything completely is rational and uncertain, including legal issues must be no certainty. The purpose of legal certainty is to protect the rights of individuals. Indonesa society is a society that does not highlight the rights of individuals. If the legal system was born in the liberal-individualist ideology which is implemented in Indonesia, it would appear injustice conditions. While Indonesia is collective society that does not accentuate an individual interests, but 'shared interests'. That is why the laws are made by basing liberal-individualist ideology, the Indonesian Penal Code immediately replaced or updated as the kinship concept based on the values of Pancasila as an ideology of the Indonesia. The value of justice will be realized in Indonesian society.

\section{BIBLIOGRAPHY}

Bambang Sutiyoso. 2009. Legal discovery method. Yogyakarta: UII Press.

Barda Nawawi Arief. 2009. A new Criminal Code draft Criminal Law System Reconstruction Indonesia. Semarang: Diponegoro University Publishing Board.

Bambang Ali Kusumo. 2012. Study on Decision MA. On the Crime of Theft. Discourse Journal of Law Faculty of Law University of Slamet Riyadi Surakarta. April 2012 edition. 
Monodualistik 2015. Balance Between Individual and Social Interests In Indonesia Criminal Law Reform. Journal of Law Faculty of Law Universitas Islam Sultan Agung (UNISSULA) Semarang. Vol. XXXI, No. 1, June 2015.

Bernard L. Tanya etc. 2010. Theory of Law (Human Conduct Cross-Space Strategy And Generation). Yogyakarta: Genta Publising.

Lili Rasyidi and Ira Thania Rasyidi. 2007. Fundamentals of Philosophy and Legal Theory. Bandung: Adita Citra Bakti.

Lili Rasyidi and Ida Bagus Putra Wyasa. Law 2012. As a System. Jakarta: Fikahati Aneska.

Mohammad Kemal Darmawan. 1994 Crime Prevention Strategy. Bandung: Citra Aditya Bakti.

Moeljatno. 1978. The translation of the Criminal Justice Act.

R. Suroso. 2013. Introduction to Law. Jakarta: Sinar Grafika.

Satjipto Rahadjo. 1991. Legal Studies. Bandung: Citra Aditya Bakti.

. Law In Order 2006. Jagat. Jakarta: UKI Press.

. 2009. The layers in Legal Studies. Malang: Bayu Media Publising.

Progressive Law 2009. A Synthesis of Indonesian law. Yogyakarta: Genta

Publising.

2009. Legal Education As a Human Education. Yogyakarta: Genta

Publising.

\section{Journals:}

Zudan Arif Fakhrulloh. 2005. Law Enforcement Creates Opportunities For Justice. Journal jurisprudence Muhammadiyah University of Surakarta.

Bulletin of the Judicial Commission, Volume VI, No. 4, January - February 2012.

\section{Verdicts:}

The Supreme Court decision. Number 653 K / PID / 2011.

\section{Newspaper:}

Republika. Thursday, March 19, 2015.

Republika. Wednesday, 14 September, 2016.

Surat Police Regulation No. Pol: B / 3022 / XII / 2009 / SDEOPS, dated December 14, 2009

On Handling Cases Through Alternative Dispute Resolution (ADR).

Bambang Ali Kusumo, SH., M. Hum. 
Lecturer Kopertis DPK Region VI Central Java at the Faculty of Law, University of Slamet Riyadi Surakarta, finishing S1 at the University of March Surakarta 1986, S2 at the Graduate Program Diponegoro University in 2003 and is currently pursuing Doctoral Program of Legal Studies (S3) at the University of Sultan Agung Semarang.

\section{Internet:}

http: // arriemarrioza, Wordpress.Co/20011/03/09. 